\title{
Accounting Research in the Cornell Quarterly: A Review with Suggestions for Future Research
}

\author{
Cornell Hospitality Quarterly \\ $5 \mathrm{I}(4) 502-512$ \\ (C) The Author(s) 2010 \\ Reprints and permission: \\ sagepub.com/journalsPermissions.nav \\ DOI: | 0.1 | 777/| 9389655|0375030 \\ http://cqx.sagepub.com
}

@SAGE

\author{
James W. Hesford and Gordon Potter
}

\begin{abstract}
An analysis of accounting-related articles published in the Cornell Hospitality Quarterly shows a shift from prescription to description, with an increasing use of scientific research methods. The authors found that the literature has examined the industry's use of the Uniform System of Accounts, cost management, and management control systems, including the effects of nonfinancial measures and the balanced scorecard. Although a uniform system of accounts offers consistency, it may limit a hotel manager's ability to match costs with departmental revenues. Budgeting and capital budgeting are particularly difficult issues for the hospitality industry, due to the fact that most hotels involve independent parties as ownership and management. One oddity of the hospitality industry is that few managers adjust budgets to reflect operational outcomes. In addition to their review, the authors provide suggestions for future research.
\end{abstract}

\section{Keywords}

hotel management; restaurant management; hospitality accounting; Uniform System of Accounts; balanced scorecard; budgeting

In this article, we review a number of accounting research papers that have been published in the Cornell Quarterly. Our goals are to recognize much of the accounting research that has been completed to date and to provide some suggestions for future work in this area. In selecting papers for review, we undertook a keyword search and reviewed the titles in each issue. We decided to put greater emphasis on more recent papers since in the early years of the Cornell Quarterly, most articles were either simply descriptive of practice or normative. ${ }^{1}$ We limit our discussion of such papers, focusing more on those that contribute to the positive science of accounting research.

In recent years, there has been a paucity of accounting research in the Cornell Quarterly (Canina 2008). This is unfortunate for two reasons. First, accounting has been shown to be a critical success factor in organizations, and thus a lack of good accounting has been a factor in failing organizations (Parsa et al. 2005). Second, accounting practice has recently undergone significant changes with innovations like activitybased costing and the balanced scorecard. Many of these practices are finding their way into hospitality firms. Accounting research is needed to understand how such innovations perform and what, if any, adaptations are needed.

We begin by summarizing some of the key accounting research presented in the Cornell Quarterly. In general, we do not include studies on revenues, traditional capital budgeting, and ratio analysis as this would reduce the focus of the article and because many of these issues are covered elsewhere. A list of the research papers we review is contained in Exhibit 1. Not surprisingly, all except two of them address the hotel industry. Moreover, a vast majority of studies use the survey method. For ease of exposition, we partition the studies into issues involving accounting practice, cost management, and strategic management controls. Where applicable, we conclude each topic with some suggestions for future research.

\section{Accounting Practice}

Other than discussing the uniform system of accounts below, we do not discuss in detail external financial reporting issues as there have been only a few articles in the Cornell Quarterly on this subject, and these are all prescriptive. For instance, Geller (1978) describes different accounting methods to address inflation's impact on the financial statements of hotels. Geller and Heath (1981) present a justification for a cash flow statement in the financial reporting model of lodging properties. They argue that owners need the information to effectively manage their properties. The piece is noteworthy for preceding the Financial Accounting Standards Board (FASB) adoption of the cash flow statement. Schmidgall, Geller, and Ilvento (1993) illustrate a number of ratios that 
Exhibit I. Accounting Research in the Cornell Quarterly

\begin{tabular}{|c|c|c|c|c|c|}
\hline Authors & Year & Industry & Method & Data & Topic \\
\hline Banker, Potter, and Srinivasan & 2005 & Hotel & Empirical & Archival & Nonfinancial measures and future financial performance \\
\hline Chan and $\mathrm{Au}$ & 1998 & Restaurant & Empirical & Survey & Components of restaurant costs \\
\hline Chow, Wright, and Haddad & 2000 & Hotel & Experiment & Survey & Escalation of commitment: sunk costs \\
\hline Denton & 1998 & Hotel & Empirical & Case & Model of annual ongoing capital expenditures \\
\hline Denton and White & 2000 & Hotel & Empirical & Case & Implementation of balanced scorecard \\
\hline Dittman and Hesford & 2007 & Hotel & Simulation & Multiple & Monte Carlo simulation of a capital investment decision \\
\hline Dunn and Brooks & 1990 & Hotel & Simulation & Case & Design of a customer profitability model \\
\hline Enz, Potter, and Siguaw & 1999 & Hotel & Empirical & Archival & Impact of variety on revenue, costs and profits \\
\hline Geller & 1985 & Hotel & Empirical & Survey & Critical success factors and performance measures \\
\hline Geller, Ilvento, and Schmidgall & 1990 & Hotel & Empirical & Survey & Activities of hotel controllers \\
\hline Goldman and Eyster & 1992 & Restaurant & Empirical & Survey & Outsourcing decision \\
\hline Huckestein and Duboff & 1999 & Hotel & Empirical & Case & Implementation of balanced scorecard \\
\hline Karadag and Kim & 2006 & Hotel & Empirical & Survey & Demand for customer profitability information \\
\hline Kosturakis and Eyster & 1979 & Hotel & Empirical & Survey & Budgeting practices of small hotels \\
\hline Kwansa and Schmidgall & 1999 & Hotel & Empirical & Survey & $\begin{array}{l}\text { Usage and understanding of Uniform System of Accounts } \\
\text { for the Lodging Industry (USALI) }\end{array}$ \\
\hline Morey and Dittman & 1995 & Hotel & Empirical & Archival & $\begin{array}{l}\text { Data envelopment analysis (DEA): relative performance } \\
\text { evaluation }\end{array}$ \\
\hline Morey and Dittman & 2003 & Hotel & Empirical & Archival & DEA: examination of factors impacting hotel profitability \\
\hline Nordling and Wheeler & 1992 & Hotel & Empirical & Case & Market segment profitability \\
\hline Quain & 1992 & Hotel & Simulation & Case & Design of a customer profitability model \\
\hline Schmidgall, Damitio, and Singh & 1997 & Hotel & Empirical & Survey & Accounting for ongoing capital expenditures \\
\hline Schmidgall and DeFranco & 1998 & Hotel & Empirical & Survey & Budgeting practices of hotels \\
\hline Tracey and Hinkin & 2008 & Hotel & Empirical & Survey & Costs of employee turnover \\
\hline Upneja and Schmidgall & 2001 & Hotel & Empirical & Survey & Leasing practices of hotels \\
\hline
\end{tabular}

could be generated using the information from the cash flow statement. We are unaware of any empirical research in the Cornell Quarterly or elsewhere that documents the benefits to the industry of these financial reporting methods. ${ }^{2}$

\section{Uniform System of Accounts for the Lodging Industry}

Kwansa and Schmidgall (1999) provide an interesting perspective on the use of the Uniform System of Accounts for the Lodging Industry (USALI). The system was developed by the Hotel Association of New York City in 1926 and is currently in its tenth edition. Kwansa and Schmidgall examined the usage of the system by surveying 112 accounting professionals, primarily controllers, in the lodging industry. Nineteen percent of the responses were from independent properties, while the remaining were either corporate properties or affiliated with national chains. The authors addressed three issues in the survey: (1) the extent of usage of the USALI; (2) the perceived benefits of the accounting system; and (3) the respondents' knowledge of the system, which seemed to be only good at best. As for USALI use, 78 percent of the respondents stated their property used the system, primarily given the demands of corporate. In fact, the survey participants ranked the importance of the USALI higher than
FASB pronouncements and the Internal Revenue Code. This was particularly true for individuals at corporate properties. Among the perceived benefits, respondents overwhelmingly thought the principal benefit related to the standardized reporting that enabled comparability and consistency. As is clear in the review that follows, the quest for uniformity in external reporting may compromise the system's usefulness for effective management of the property's operations.

\section{Accounting for Ongoing Capital Expenditures}

One important accounting issue in the lodging industry that is not satisfactorily addressed in the USALI or elsewhere is the delineation between normal ongoing maintenance expenditures, which are expensed as incurred, and capital expenditures, which are incurred to increase or improve operating capacity and are thus capitalized as an asset. Given that in many hotels the day-to-day operations are run by managers who are separate from the owners, Denton (1998) discusses the well-known conflicts in the choice of capitalizing versus expensing these amounts. Because operating managers are generally only responsible for operating expenses, these managers have an incentive to capitalize as much expenditure as possible. Denton identifies three possible negative consequences of excess 
capitalizing: (1) the owner's tax liability will increase as less maintenance expenditures are recognized as an expense, (2) the operator is likely to make many low-priority renovations rather than save funds for major improvements, and (3) the management company may be tempted to cut corners on maintenance and generally defer charges until the necessary expenditure becomes so large that it must be capitalized. He continues by providing a capital expenditure planning model that he suggests may help owners hold management accountable for maintaining assets.

Schmidgall, Damitio, and Singh (1997) present a study illustrating the difficulty of the capital expenditure classification decision by lodging companies. They sampled seventythree property-level controllers who were members of the International Association of Hospitality Accountants (IAHA). The median amount of capital expenditures for the sample was $\$ 650,000$ on median revenues of $\$ 12,500,000$, for a capital expenditure budget of about 5.2 percent of revenues. One key finding of the study was that 62 percent of the respondents were uncertain as to when an expenditure should be capitalized. The controllers' responses revealed that the criteria they most often used for capitalizing the purchase of a piece of equipment (such as furnishings or furniture) tended to be based on whether the purchase was part of a renovation or when the purchase was over a certain dollar amount. An extension of useful life was also recognized as a criterion. As for capitalizing expenditures related to a repair or renovation, capitalization typically occurred if the expenditure extended the useful life of the asset or the improvement was over a certain dollar amount. Surprisingly, few controllers justified capitalization of an expenditure based on an improvement in the earning capacity of the asset.

The study is important in documenting that 73 percent of the respondents felt that guidelines for capitalizing are needed. However, there was substantial disagreement over the authoritative body that should establish the guidelines. Respondents mentioned the IAHA, the FASB, and the American Institute of Certified Public Accountants (AICPA) as possible authoritative bodies for this work. In concluding, the authors suggested the item be addressed by the authors of the USALI. The topic was not addressed in the 2006 revision, and the capitalization decision continues to be a problem today. Future work in this area may help define the magnitude of the problem and offer other possible solutions to the capitalization decision.

\section{Allocation of Service Department Costs}

One of the key impacts of following the USALI is that, to facilitate comparability across properties, there is little allocation of expenses to departments and other cost objects. Rather, the measured departmental profit of the revenue producing departments, such as the rooms and food and beverage departments, only include a subset of direct expenses that can be easily ascribed to the department. For instance, credit card fees and franchise fees are not assigned to revenue producing departments even though it would be quite easy to achieve. Many other departments, such as security, marketing, and human resources, are operated as cost centers. Articles by Lesure (1973) and Geller and Schmidgall (1980) discuss the possible benefits and costs of allocating more costs to the revenue producing departments. Lesure points out that cost allocation benefits might include a better understanding of the full cost of providing a good or service and, thus, help in pricing or in directing the efforts of the marketing department. In addition, the article notes that another allocation benefit is helping managers become more cost-aware, or costconscious. The cost allocation process helps managers better understand the relationships between departments and thus help promote the efficient use of resources.

Geller and Schmidgall (1980) also note that documenting the "full cost" of a product or department can provide justification for setting wage and price guidelines and for government per diem rates. A potential drawback of cost allocations is the impact of the allocation on a department manager's willingness to use a resource. Geller and Schmidgall (1980) state that if cost allocations occur, department heads may defer needed service (e.g., maintenance) to achieve short-run profitability at the expense of the long-term health of the business. While both studies provide a few examples of the cost allocation process and argue that there are clear benefits from allocating, these studies provide little overall documentation of the benefits and costs of allocation. It would be interesting to determine the extent to which properties allocate these costs and, if they do so, to ascertain whether there are any benefits from this process. For instance, Redlin and Goland (1984) state that hotels could realize substantial cost savings by tracing their energy and water usage to operating departments and then ascribing the expense of these resources to these departments. However, we are unaware of any empirical work that has systematically addressed these issues.

\section{Cost Management}

\section{Product Costs}

Few articles address product costs in hospitality firms. The profitability of products in restaurants has often been calculated as revenue minus direct material expense (i.e., food cost), despite significant labor and overhead expense. With this in mind, Chan and Au (1998) studied the significance of various cost categories and the factors that affected quantification of costs. Using a mail survey of hotels, clubs, and Chinese restaurants in Hong Kong, they found that material cost was the largest share of total cost (33 percent). Despite direct labor being 20 percent of total cost, most restaurants were unwilling to invest in accounting systems needed to improve product 
cost accuracy. Similarly, energy was seen as not worth measuring and was pooled into fixed overhead. With quarterly updating of menus, less frequent cost system updates, and lack of measurement, product costs were often inaccurate. Chan and Au conclude that improved costing would be beneficial to restaurants, advocating research on prototype cost systems and focusing on products with high volumes or long preparation times. Anecdotally it appears that many large-scale restaurant chains have good management and operational cost controls, but there has been a paucity of research to confirm these observations. In particular, we suspect the development of full product costs, or product line costs, would enhance restaurants' overall performance.

\section{Employee Productivity and Turnover Costs}

Labor cost percentage has been, and sometimes still is, used as the sole means to assess worker productivity. However, in almost every control situation, focusing on a single measurement is a bad strategy. Pavesic (1983) makes this case by comparing two restaurants with identical labor expense. One has higher revenues and, therefore, has the appearance of higher worker productivity due to a lower labor cost percentage. But additional measures described demonstrate that, in the second restaurant, worker productivity is higher. Failure to incorporate additional measures would result in lost profits from low productivity.

Employee turnover in the hospitality industry is quite high, and its impact on productivity and costs is still being analyzed. Turnover costs and the factors associated with turnover are the principal objectives of Tracey and Hinkin (2008). Data were collected from thirty-three hotels using a web-based survey instrument. Respondents provided information on cost related to turnover along with data on the organization and the associated positions. ${ }^{3}$ Jobs were classified as to their complexity, and organizational data collected consisted of room rates, property size, chain affiliation, and occupancy. Tracey and Hinkin split their data into natural (chain affiliation, rates) and high and low categories (size, occupancy, complexity), and turnover costs were reported for each type of split. Firms were also split into categories based on low and high total turnover costs, and activities within the five major cost classifications were compared. Drawing on these six splits, the authors concluded that turnover costs were highest for complex jobs, large hotels, and upscale hotels.

With these findings, we encourage additional research, as most of Tracey and Hinkin's (2008) comparisons were not statistically significant due to their small sample size. ${ }^{4}$ With larger studies, researchers can examine interactions between factors that may impact total turnover costs. Future research would also benefit from a more complete analysis of capacity issues, as average costs in the presence of unused capacity may significantly overestimate the cost of turnover. Such an analysis may explain why high turnover persists despite years of apparently suboptimal behavior on the part of hospitality firms. An examination of activities in Tracey and Hinkin also suggests that future research may benefit from a time-driven, activity-based costing model. Kaplan and Anderson (2007) discuss this new approach to costing. ${ }^{5}$

\section{Customer Costs and Profitability}

Accounting research has focused almost exclusively on cost drivers despite the obvious importance of understanding the “top line" behavior of revenues. O'Neill and Mattila (2006) examined the impact of numerous revenue drivers on net operating income. Using two years of archival data from 1,954 hotels, the authors used a hierarchical regression approach to determine whether hotel occupancy and average daily rate (ADR) provided additional explanatory power beyond that provided by six demographic variables. They found that higher occupancy was critical in driving higher profitability, and it was significantly more important than ADR. This result contradicts the accepted wisdom that hotels are better off trading higher ADR for relatively lower occupancy. With a recent empirical study by Enz, Canina, and Lomanno (2009) providing empirical support for the accepted wisdom, future research is needed to settle this important issue.

Enz and Potter (1998) examined factors explaining differences in operating expenses for a number of properties in a full-service hotel chain. In addition to documenting that operating expenses (many of which are traditionally considered to be fixed) increased with occupancy rate and other control variables, they documented that properties realize economies of scale but diseconomies of scope. Specifically, diseconomies of scope were documented because properties catering to a number of customer segments had higher operating expenses than those properties focusing on one or few customer segments. Enz, Potter, and Siguaw (1999) found that at this research site, not only did serving a larger variety of customer segments increase operating costs, but the cost increases were not fully compensated for by a similar increase in net revenues. Thus, efforts to increase revenue sources through new customer bases may be unprofitable, a finding that helps motivate customer profitability analysis.

Under the current reporting requirements for lodging properties, the tenth edition of the USALI, expenses are grouped by operating departments. While the rooms and food and beverage department are also assigned revenues, and thus performance is reported as departmental profit, many other operating costs are retained in departments operated as cost centers. Under this system, there is a general lack of information on the overall profitability of customer segments. Information on customer profitability would be useful for determining a property's optimal market mix; pricing strategies; and marketing 
efforts, such as advertising and sales promotion activities. There have been a few articles in the Quarterly attempting to measure customer profitability. A case study by Quain (1992) describes a method for assessing a segment's contribution to profits. The analysis is undertaken using a prototypical property. Thus, there is no way to know how effective the method is in measuring a customer segment's contribution. Moreover, the study only allocates a few cost differentials across customer segments and, thus, principally focuses on a customer net revenue contribution. Nordling and Wheeler (1992) describe a case study of the Las Vegas Hilton's approach to assessing the profitability of different customer segments. While the study is informative and uses an actual property, little of the undistributed operating expenses were assigned to market segments.

Roadblocks to developing reliable customer segment profitability measures can be gleaned from the study by Karadag and Kim (2006). These authors conducted a survey to examine the perceived value of customer segment profitability information to marketing and accounting personnel. They argued that "the difficulty for hotel managers is that they are caught between spending money according to different customer groups and accounting for that spending according to a system that allocates expenses by department" (p. 160). Thus, in their view, there is little information to guide managers' spending efforts or to conduct appropriate performance evaluation. Karadag and Kim compared the responses of 143 accountants (primarily property controllers) to those of 86 marketing personnel (mainly directors of sales and marketing). Approximately 30 percent of the respondents worked for independent properties, with the remaining working in chain-owned or franchised properties. Most of the respondents represented upscale or midscale properties.

Not surprisingly, Karadag and Kim (2006) found that a much larger percentage of marketers (45 percent), versus 13 percent of accountants, agreed with the statement that all company costs should be allocated to customer segments. The study also determined that 67 percent of the marketers, but only 24 percent of the accountants, were using any method to assess customer profitability. Reasons for not using customer segment analysis included that the information was not requested by management or that it is not provided for in the USALI. Both groups acknowledged that current accounting systems are designed to measure department profits, not market segment profits, and that their methods for measuring the full costs of services provided to customers were lacking.

Karadag and Kim (2006) concluded that the USALI stresses uniformity, and thus the accounting system does not provide the necessary information for market segment analysis. They proposed that a new systematic approach to measuring customer profitability should be developed. Much research needs to be done to develop a model that accurately reflects resource consumption patterns by customers. A theoretical case study by Dunn and Brooks (1990) provides an interesting, detailed activity-based costing approach to obtaining costs by customer segments. As in the Quain (1992) study, the Dunn and Brooks model is derived using a prototypical hotel. Clearly, more work can be completed in this area using real data tested over multiple periods or properties. There is much to learn from empirical work in this area about the accuracies of these systems and their effectiveness in leading to better decisions and performance.

\section{Management Controls \\ Sunk Costs: The Escalation of Commitment}

Managers are often faced with decisions about whether to commit resources to a project or activity in the face of feedback that suggests further commitment is a waste of organizational resources. Staw (1976) observed that individuals who will be held responsible for failure are likely to justify past decisions using "retrospective rationality." The combination of a manager possessing private information about the likelihood of a project's success and incentives to prevent failure is known as the escalation of commitment problem (Conlon and McLean Parks 1987; Arkes and Blumer 1985; Garland 1990). To examine this problem in the hotel industry, Chow, Wright, and Haddad (2000) conducted three mail surveys of executives in one firm. The first study surveyed twenty-eight executives at twelve hotels and asked the extent to which escalation of commitment occurs and the extent to which the behavior impacts hotel profitability. Using Likert-type scales, about half of the responses were above the scale midpoint, indicating that executives believe escalation of commitment is a problem.

In a follow-up study, participants provided a list of potential causes of escalation and rated the degree of importance of each item as related to their hotel property. All of the causes were perceived as moderately important, and these were placed into a management control framework of action controls, results controls, personnel controls, and cultural controls (Merchant and Van der Stede 2007). The management control framework facilitates an understanding of the coordination of control mechanisms needed to limit opportunistic behavior. A third study was an experiment designed to provide evidence of individual intentions rather than the perceptions that were the focus of the first two studies. Twenty different participants were given a scenario where they possessed private information that a project was going to become less profitable in future years and where termination of the project would be personally costly (e.g., damaged reputation, loss of future opportunities). Results were consistent with the first study, finding that half of the participants indicated a willingness to escalate their commitment.

A notable attribute of the hospitality industry is the large number of company locations, with many hospitality firms 
having hundreds or thousands of managers. Accordingly, management control in the hospitality industry is more challenging and important than in most other industries. The Chow, Wright, and Haddad (2000) paper, therefore, makes an important contribution to the hospitality literature. From a methodological perspective, the use of multiple studies within a single paper is a positive and important feature of the research design.

\section{Budgeting}

Using a survey of 319 accountants in the lodging industry, Geller, Ilvento, and Schmidgall (1990) found that activities of hotel controllers included processing of receivables, payables, payroll, and general accounting. Controllers had a key involvement on the property's executive committee and longrange planning committee. Budgeting is a key activity undertaken by most business organizations. Kosturakis and Eyster (1979) surveyed the budgeting practices of fifteen small hotel companies that on average operated nine properties and approximately two hundred rooms. They found that the primary perceived benefits dealt with coordination and control issues, rather than planning. There were two other interesting findings from the study. One was that budget accuracy was not related to the aggressiveness of the budgeting estimates. Specifically, those companies that had conservative budget approaches were no more accurate than those firms that were quite aggressive in their estimates. In addition, the authors found that while the respondents felt that the biggest problem in developing accuracy was related to the impact of economic events, few if any of the firms used flexible budgeting techniques for performance evaluation. Rather, budgets remained constant over the reporting period.

Schmidgall and DeFranco (1998) examined the budgeting practices in the lodging industry. Their findings are based on a survey that was administered to 171 accountants in the lodging industry. Most of the respondents were controllers in fullservice properties. The study addressed the primary reasons for budgets, budgeting goals, and forecasting techniques. Two reasons seemed to dominate the need for budgets. Twentyeight percent of the respondents said that the primary purpose of the budget was its use as a planning tool. Thus, the operations budget was be used to coordinate activities and ensure the availability of resources. Forty-five percent claimed that the key purpose of the budget is to provide a standard by which a lodging property is managed. Surprisingly, however, only 25 percent of the controllers stated that their budgets were adjusted during the period as conditions warranted. This would seem to be critical, as benchmarks should be adjusted as conditions change during the period.

Other findings of the study concern the existence of a forecast goal and the approaches used by controllers to forecast revenues. A full 60 percent of the respondents claimed that their budgets started with a tentative financial goal prior to preparing the budget. About a third used sales as the goal; a third used net income as the goal; and the remaining used measures such as revenue per available room (RevPAR), gross operating profit, debt service coverage, EBITDA (earnings before interest, tax, depreciation, and amortization), or some combination of the measures. The survey results also indicated that the sales forecasting techniques varied across departments. Rooms tended to forecast based on expected units sold, food and beverage based on expected number of guests, and banquets using the prior year's revenues. The vast majority of respondents claimed that their budgets were used for cost control. Cost tolerances were about 2 percent for food and beverage and 3 percent for labor and other operating costs.

The common theme of the two studies is that the most properties do not adjust their budgets during the period as conditions warrant. From a cost control perspective, however, designing flexible budgets is felt to be critical for inducing managers to adjust activities and thus costs as conditions warrant. It would be interesting to learn if there is some other mechanism that firms use to adjust costly resources during a period as conditions change.

\section{Capital Budgeting}

Traditional methods of modeling investment decisions in the hotel industry make use of net present value calculations where expected values of demand, prices, and costs are known. As these are covered in many finance papers, they are not addressed here. Dittman and Hesford (2007) is a case study illustrating the application of an alternative capital budgeting technique: Monte Carlo simulation. The objective of their study was to illustrate how hoteliers can determine the optimum number of allergy-free rooms to build out and the price premium for the converted rooms. Survey data from 329 individuals were combined with occupancy data from a hotel in New York. From the survey data the authors created a demand curve for allergy-free rooms. With no uncertainty in hotel occupancy, demand for allergy-free rooms is simple to calculate, as the decision maker simply sets price and number of rooms to maximize the net present value of discounted cash flows.

With fluctuating demand, there are days when allergy-free rooms will go unoccupied, while on remaining days demand will exceed capacity. Calculating price and quantity of rooms, then, is more complicated. A solution to this problem is a technique known as Monte Carlo analysis. For uncertain variables, Monte Carlo analysis draws numbers at random from specified distributions. With the numbers drawn, the equation is solved and the result recorded. This process is repeated thousands of times to simulate the many possible outcomes in nature, and the results are an empirical distribution. By graphing outcomes, decision makers are able to visualize risk. 
Dittman and Hesford (2007) demonstrate that with uncertainty in occupancy, the optimum decision differed between an expected value calculation and the Monte Carlo approach, the latter method being correct. Had the decision maker used an expected value approach, realized net present value would likely be 7.8 percent below optimum. While illustrating one decision, simulation can be used for a broad range of investment decisions involving uncertainty.

\section{Relative Performance Evaluation: DEA Benchmarking}

Benchmarking is an important topic in accounting because of its use in relative performance evaluation. Many firms, such as Southwest Airlines, have sought to use these techniques to eliminate the effects of changing or different market conditions across locations. Two studies demonstrate the use data envelopment analysis (DEA), a technique to measure managerial performance in the hotel industry (Morey and Dittman 1995, 2003). The authors' model incorporates multiple outputs, controllable inputs and noncontrollable variables, creating an "efficient frontier" that provides benchmark data. Comparing benchmark data to actual profits provides insights into inefficiencies that lead to suboptimal profits. In their more recent study, Morey and Dittman (2003) found that a 1 percent increase in a composite service index resulted in a 0.96 percent increase in hotel profitability. They were similarly able to quantify profit increases from increases in efficiency scores, occupancy, ADR, and room size. These results demonstrate that additional research in other sectors of the hospitality industry (e.g., restaurants and airlines) would be a welcome addition to the literature. Articles demonstrating the use of alternative analytical tools, such as stochastic frontier estimation (SFE), would be a useful addition to the literature. Dopuch and Gupta (1997) provide an illustration of SFE in evaluating the performance of school districts.

\section{Nonfinancial Performance Measures}

Incorporating nonfinancial performance measures into the management control systems of hospitality firms is an important issue that has been covered in a few articles. More than two decades ago, Geller (1985a, 1985b) presented an overview of executive information needs based on survey results and interviews of seventy-four executives at twenty-seven lodging companies. He examined the critical success factors that executives felt they needed to attain to meet the company's goals. While he hypothesized that company-specific goals would require different critical success factors, he found that certain critical success factors were fairly universal. Specifically, while most executives' goals concerned profitability and growth, his research revealed that the overwhelmingly majority of executives cited employee attitudes, guest satisfaction, and a superior product as the most critical success factors. He then discovered that many of the most often mentioned performance measures used to monitor critical success factors dealt with employee attitudes and guest satisfaction. His findings suggested, however, that much of the tracking of these nonfinancial measures was done on an ad hoc basis. Since his studies, hospitality firms have more thoroughly defined their nonfinancial performance measurement systems.

Many firms have adopted performance measurement systems using aspects of the balanced scorecard developed by Kaplan and Norton (1992). In their study, Kaplan and Norton reasoned that including nonfinancial operational performance measures related to customer perceptions, internal business processes, and innovation and improvement would help managers focus on the drivers on future financial performance. Moreover, these measures could represent the key elements of a company's strategy. Two description of the design and impacts of the adoption of the balance scorecard have appeared in the Quarterly. Huckestein and Duboff (1999) describe the implementation of a balanced scorecard at Hilton Hotels in the late 1990s. During this period, the company had adopted an aggressive growth strategy. However, the firm was struggling with inconsistency across properties. The balanced scorecard was adopted to address disparities in the guest experience.

Hilton Hotels changed its business design to have employees focus on those actions that delivered value. The balanced scorecard became the means by which the company translated strategy into operational measures. Eight measures were included in the new performance measurement system. Three were financial measures including RevPAR, RevPAR index, and EBITDA. Also included were the following five nonfinancial performance measures: customer satisfaction measured from guest comment cards, customer satisfaction measured from customer tracking surveys, employee satisfaction, mystery shopper scores, and audit of brand compliance. These measures were also linked to the bonuses, performance reviews, and stock-option grants of employees. To aid in identifying areas to improve the customer experience, detailed responses from customers were also monitored when needed. Huckestein and Duboff (1999) reported that the initial results from the new performance measurement system were promising. Hilton's owned and managed properties improved their RevPAR and RevPAR index against competitors. More important, franchised properties that implemented the plan demonstrated "tremendous" RevPAR index improvement. The authors also state that customer opinions and overall satisfaction scores strongly increased, as did Hilton's J.D. Power and Associates measures. While the study reported little regarding changes in employee and process measures, the authors claimed that an independent consultant's analysis found that employee responses to the program were positive. However, it is not 
clear whether the balanced scorecard provided the desired consistency across properties.

Denton and White (2000) describe the design and implementation of a balanced scorecard at a hotel management company that at the time operated thirty-eight limited-service properties. The performance measurement system's goal was to track, in addition to financial information, nonfinancial measures that were believed to be important for long-term growth and value creation. It was also to be aligned with the owners' objectives, simple to monitor and easy for managers to understand (p. 96). With the exception of the financial measures, the performance measurement system included one measure for each dimension of the balanced scorecard. The company used a RevPAR index and a flow-through measure of profitability that compares actual profit to expected profit given actual output (rooms sold). As such, this latter measure focuses on cost control. Scores from a guest satisfaction survey were used as the measure of customer expectations. Internal processes were measured using a process audit measure that was conducted by the manager of internal audit. Finally, employee turnover was used as the measure for learning and growth. The authors report that over a three-year period, starting one year prior to implementation and ending one year after implementation, there was improvement on many measured dimensions. Financially, the RevPAR index and profit margin both improved over the two-year period. Moreover, employee turnover dropped dramatically and audit scores increased. However, customer satisfaction scores dropped during this period. While the results are interesting, they are for a short period of time and are not entirely consistent with the predictions of the balanced scorecard.

The above case studies, although encouraging, provide little empirical evidence on the value of implementing nonfinancial performance measurement systems. Banker, Potter, and Srinivasan (2005) was one of the first studies to document how a bonus plan that includes nonfinancial performance measures impacts financial performance. Two important differences between their study and prior research was the inclusion of an institution-specific, long time series of observations and detailed field interviews of a company's nonfinancial performance incentive plan implemented in the mid-1990s. Using time-series data for seventy-two months from eighteen hotels managed by a large hospitality firm, the study documented that simple nonfinancial measures of customer satisfaction, specifically number of customer complaints and likelihood of the guest to return, were significantly associated with future financial performance after controlling for past financial performance. The analysis indicated that the positive association between future revenues and current nonfinancial performance is mainly driven by occupancy (volume effect) as opposed to room rates (price effect). More important, the authors found that both nonfinancial and financial performance improved at these hotels following the implementation of the bonus plan that included nonfinancial performance measures.

Albeit limited to data from one firm, the study provides formal empirical evidence on the performance impacts of an incentive plan that includes both financial and nonfinancial performance measures. As such, it documents potential benefits of nonfinancial measures in contracting. The study also investigated the impact of the incentive plan on the hotel chain's performance. Specifically, it examined the growth in the total annual number of rooms supplied and total annual revenues under the hotel's brand. This analysis was conducted after controlling for the growth in the industry using the number of rooms supplied and revenues by the upscale and midscale hotel chains in the United States. Banker, Potter, and Srinivasan (2005) found that both the number of franchised hotels and the chain's total revenues increased more than those of its competitors following the implementation of its new incentive plan. This finding provides one more rationale for the use of customer satisfaction measures in performance evaluation in the hotel industry, where such externalities are important. The study did not examine a plan that incorporated the entire balanced scorecard. Research into the impacts of balanced scorecard systems would be fruitful.

\section{Control with Outsourcing and Leasing}

A number of hotels outsource food and beverage to third parties such as restaurant chains or independent operators. The pressure to outsource comes from the belief that food and beverage operations are less profitable than lodging and, furthermore, are ancillary to the room business, which has become most hotels' main product. To understand the nature and effectiveness of food and beverage leases, when hotels outsource, Goldman and Eyster (1992) conducted survey research of restaurants in one hotel chain. Respondents provided data on key lease provisions, uncertainty, and the tensions that exist between the contracting parties. The tensions that developed were associated with coexistence, the maintenance of corporate standards, and goal alignment. To validate their results, the authors conducted follow-up interviews with a hotel firm and a consultant.

Goldman and Eyster (1992) identified three critical success factors for restaurants: rent structure, the ability to attract local customers, and banquet sales. Success was defined in terms of good relations with the hotel and satisfactory financial returns. Restaurant chains were less successful, a result they attributed to slower responsiveness and higher expenses (for corporate overhead in marketing and "middle management"). This result is perhaps surprising since marketing should drive local customer business (an identified critical success factor), and centralized controls should reduce inefficiencies. In addition, economies of scale should drive lower materials costs. It is possible that the slower responsiveness 
led to lower banquets sales, offsetting the chains' inherent advantages. These issues were not addressed in the Goldman and Eyster study and, thus, represent an opportunity for future research. Future studies might also examine the impact of the inconsistency that independents would bring to a hotel's different locations and the possibility that independents have higher failure rates. As this study focused on one hotel chain and the examination of just a few lease provisions, it would be useful to examine more hotel chains.

With a significant growth in leasing outside the hospitality sector, Upneja and Schmidgall (2001) undertook a survey of leasing practices within hotels. One hundred two respondents from Hospitality Financial and Technology Professionals (HFTP) provided data on items leased, lease characteristics, incidence of capitalization, perceived advantages of leasing, and predictions on the future of leasing. Seventy-five percent of respondents reported leasing equipment. Typical leased items were photocopiers, vehicles, and communication equipment. Upneja and Schmidgall found that that principal reasons for leasing were to protect equipment from obsolescence, reduce income taxes, and smooth cash flows. While the majority of leases were treated as operating leases, transfer of ownership and bargain-purchase options were most often cited as triggers for capitalization. None of the respondents anticipated an increase in leasing, with 42 percent expecting practices to remain steady and 45 percent expecting a marginal decrease. Just 6 percent thought there would be a significant drop in leasing activity. Future studies might examine leasing practices for high-valued assets, as the results may differ from those of Upneja and Schmidgall.

\section{Other Control Issues}

Other control pieces that are more prescriptive include work by Caraux and Geller (1977) on effective cash management system within hotels. Reducing cash tied up in the organization and depositing funds more quickly into bank accounts provides investment opportunities or reduced interest expense. Reynolds (1999) describes inventory turnover analysis and how it can facilitate control (i.e., lower levels of waste and theft). Ferguson and Selling (1983) presents a tutorial on variance analysis, an accounting technique that provides insight into operational efficiency and enables management control. Using a hypothetical restaurant, the authors show how restaurants can adapt variance analysis, highlight benefits, and discuss several limitations. Responsibility accounting is a system for evaluating managerial performance based on activities they control. Madden and Thor (1976) explain this accounting concept and illustrate its application in a midsize, full-service hotel. With the rapid growth of franchising in the 1960s came financial abuses. Leone (1970) discusses accounting issues in franchising and efforts to protect investors, banks, and franchisees.

\section{Conclusion}

In the past fifty years, the accounting research in the Cornell Quarterly has evolved from mainly prescriptions to more scientific tests of theories and management practices. Authors have contributed to an understanding of most accounting topics, including budgeting, costing, and performance measurement. The review above suggests a few avenues for future research. One issue is the impact of the uniform system of accounts on management behavior and the use of alternative sources of information. We have seen that the USALI limits the allocation of costs for the reporting goal of uniformity. However, properties are still free to allocate costs to ascertain customer profitability and to induce efficient consumption of resources. Little is known about whether these allocations are occurring and, if so, whether they are beneficial. Another area that seems perplexing is the lack of flexible budgets at properties. In general, we know little about how costs behave at the property level. Few if any studies to date have addressed all of a property's operating costs. How do managers effectively manage activities and costs without budgets that adjust for changes in output? Finally, most hospitality companies are implementing nonfinancial performance measurement systems. While we know some of the links between measures, much more research is needed concerning how the nonfinancial measures interact and how costly it is for properties to attain satisfactory levels on these dimensions. This is an area that could potentially lead to conflicts between operating managers, franchisors, and owners. We are unaware of any studies addressing these potential conflicts and believe research on these issues would be beneficial.

With the exception of one simulation, the published articles have all used empirical archival methods. Moreover, most data have been obtained from surveys, use qualitative data, and only provide summary descriptions of practice. There are few large-sample studies using reliable data over a wide range of activities and management practices. What is also missing - and would benefit the Cornell Quarterlyare articles using experimental and analytical methods. As hospitality is the world's largest industry, and one with distinct characteristics, accounting research in hospitality can contribute both to accounting practice and to the broader academic literature in accounting.

\section{Notes}

1. That is, the early articles advocated what ideal accounting practices should be. A literature that develops from such ideals is known as a normative science, whereas a positive science is one that concerns "what is" (Keynes 1904; Friedman 1953). Descriptive articles are a part of positive science, but without theory and control variables their contributions are limited.

2. One piece linking the relative information content of earnings and hospitality specific performance measures on stock returns 
is Francis, Schipper, and Vincent (2003). These authors found that, although earnings were more informative than industryspecific measures in explaining stock returns, in the airline industry, revenue passenger mile, cost per available seat mile, and passenger load factor had incremental explanatory power. They also found that, in the restaurant industry, same-store sales growth was related to stock returns after controlling for earnings metrics. Again, earnings metrics dominated in the industry. No results were reported for the lodging industry, probably due to the lack of observations.

3. Prior research identified five major cost classifications: predeparture, recruitment, selection, orientation and training, and productivity loss (Hinkin and Tracey 2000). Costs were also classified as "hard," "soft," or "opportunity costs," with the latter two constituting more than half of the total cost. Whereas hard costs were recorded cash outlays, soft costs were calculated based on time estimates and wage rates. Opportunity costs are also difficult to estimate. Data provided by respondents could not be validated, and data appeared to be missing for some items.

4. Future studies must be careful to mitigate self-selection issues and errors or biases resulting from self-reporting.

5. Although not time-driven models, hints of the technique appear in cases by Narayanan $(1998,2000)$.

\section{References}

Arkes, H. R., and C. Blumer. 1985. The psychology of sunk cost. Organizational Behavior and Human Decision Processes 35:124-40.

Banker, R. D., G. Potter, and D. Srinivasan. 2005. Association of nonfinancial performance measures with the financial performance of a lodging chain. Cornell Hotel and Restaurant Administration Quarterly 46 (4): 394-412.

Canina, L. 2008. A new name for a new volume. Cornell Hospitality Quarterly 49 (1): 6.

Caraux, L. P., and A. N. Geller. 1977. Cash management: A total system approach for the hotel industry. Cornell Hotel and Restaurant Administration Quarterly 18 (3): 46-55.

Chan, W., and N. Au. 1998. Profit measurement of menu items in Hong Kong's Chinese restaurants. Cornell Hotel and Restaurant Administration Quarterly 39 (2): 70-75.

Chow, C. W., P. L. Wright, and K. H. Haddad. 2000. Increasing the effectiveness of hotels' investments: How to avoid throwing good money after bad. Cornell Hotel and Restaurant Administration Quarterly 41 (6): 49-55.

Conlon, E. J., and J. McLean Parks. 1987. Information requests in the context of escalation. Journal of Applied Psychology 72 (3): 344-50.

Denton, G. A. 1998. Managing capital expenditures using value engineering. Cornell Hotel and Restaurant Administration Quarterly 39 (2): 30-37.

Denton, G. A., and B. White. 2000. Implementing a balancedscorecard approach to managing hotel operations. Cornell Hotel and Restaurant Administration Quarterly 41 (1): 94-107.
Dittman, D. A., and J. W. Hesford. 2007. A simulation-based optimization approach for investment decisions: A case study of pure allergy-friendly rooms. Cornell Hotel and Restaurant Administration Quarterly 48 (1): 88-101.

Dopuch, N., and M. Gupta. 1997. Estimation of benchmark performance standards: An application to public school expenditures. Journal of Accounting and Economics 23 (2): 141-61.

Dunn, K. D., and D. E. Brooks. 1990. Profit analysis: Beyond yield management. Cornell Hotel and Restaurant Administration Quarterly 31 (3): 80-90.

Enz, C. A., L. Canina, and M. Lomanno. 2009. Competitive pricing decisions in uncertain times. Cornell Hospitality Quarterly 50 (3): 325-41.

Enz, C. A., and G. Potter. 1998. The impacts of variety on the costs and profits of a hotel chain's properties. Journal of Hospitality \& Tourism Research 22 (2): 142-57.

Enz, C. A., G. Potter, and J. Siguaw. 1999. Serving more segments and offering more products. Cornell Hotel and Restaurant Administration Quarterly 40 (6): 54-62.

Ferguson, D. H., and T. I. Selling. 1983. Analyzing food and labor costs. Cornell Hotel and Restaurant Administration Quarterly 24 (3): 31-39.

Francis, J., K. Schipper, and L. Vincent. 2003. The relative and incremental explanatory power or earnings and alternative (to earnings) performance measures for returns. Contemporary Accounting Research 20:121-64.

Friedman, M. 1953. The methodology of positive economics. In Essays in positive economics, ed. M. Friedman. Chicago: University of Chicago Press.

Garland, H. 1990. Throwing good money after bad: The effect of sunk costs on the decision to escalate commitment to an ongoing project. Journal of Applied Psychology 75 (6): 728-31.

Geller, A. N. 1978. Inflation: Its effects on financial statements. Cornell Hotel and Restaurant Administration Quarterly 19 (3): 28-39.

Geller, A. N. 1985a. The current state of hotel information systems. Cornell Hotel and Restaurant Administration Quarterly 26 (1): 14-17.

Geller, A. N. 1985b. Tracking the critical success factors for hotel companies. Cornell Hotel and Restaurant Administration Quarterly 25 (4): 76-81.

Geller, A. N., and L. C. Heath. 1981. Solvency, financial statements and the importance of cash flow information. Cornell Hotel and Restaurant Administration Quarterly 22 (3): 45-51.

Geller, A. N., C. L. Ilvento, and R. S. Schmidgall. 1990. The hotel controller: Revisited. Cornell Hotel and Restaurant Administration Quarterly 31 (3): 91-97.

Geller, A. N., and R. S. Schmidgall. 1980. Cost allocation: Under the uniform system of accounts for hotels. Cornell Hotel and Restaurant Administration Quarterly 21 (3): 31-39.

Goldman, K. L., and J. J. Eyster. 1992. Hotel F\&B leases: The view from the restaurant. Cornell Hotel and Restaurant Administration Quarterly 33 (5): 72-83. 
Hinkin, T. R., and J. B. Tracey. 2000. The cost of turnover: Putting a price on the learning curve. Cornell Hotel and Restaurant Administration Quarterly 41 (3): 14-21.

Huckestein, D., and R. Duboff. 1999. Hilton Hotels: A comprehensive approach to delivering value for all stakeholders. Cornell Hotel and Restaurant Administration Quarterly 40 (4): 28-38.

Kaplan, R. S., and S. R. Anderson. 2007. Time-driven activity-based costing: A simpler and more powerful path to higher profits. Boston: Harvard Business School Press.

Kaplan, R. S., and D. P. Norton. 1992. The balanced scorecardMeasures that drive performance. Harvard Business Review 70 (January-February): 64-72.

Karadag, I., and W. O. Kim. 2006. Comparing market-segmentprofitability analysis with department-profitability analysis as hotel marketing-decision tools. Cornell Hotel and Restaurant Administration Quarterly 47 (2): 155-73.

Keynes, J. N. 1904. The scope and method of political economy. 3rd ed. London: Macmillan.

Kosturakis, J. G., and J. J. Eyster. 1979. Operational budgeting in small hotel companies. Cornell Hotel and Restaurant Administration Quarterly 19 (4): 80-84.

Kwansa, F., and R. S. Schmidgall. 1999. The Uniform System of Accounts for the Lodging Industry: Its importance to and use by the hotel managers. Cornell Hotel and Restaurant Administration Quarterly 40 (6): 88-94.

Leone, R. P. 1970. Accounting issues in franchising. Cornell Hotel and Restaurant Administration Quarterly 11 (3): 13-19.

Lesure, J. D. 1973. A cost allocation system for hotels. Cornell Hotel and Restaurant Administration Quarterly 13 (4): 23-30.

Madden, D. L., and W. J. Thor. 1976. Responsibility accounting. Cornell Hotel and Restaurant Administration Quarterly 17 (1): 64-69.

Merchant, K. A., and W. A. Van der Stede. 2007. Management control systems: Performance measurement, evaluation and incentives. London: Prentice Hall/Financial Times.

Morey, R. C., and D. A. Dittman. 1995. Evaluating a hotel GM's performance: A case study in benchmarking. Cornell Hotel and Restaurant Administration Quarterly 36 (5): 30-35.

Morey, R. C., and D. A. Dittman. 2003. Update and extension to "Evaluating a hotel GM's performance." Cornell Hotel and Restaurant Administration Quarterly 44 (5-6): 60-67.

Narayanan, V. G. 1998. Lehigh Steel. HBS no. 9-198-085. Boston: Harvard Business School Publishing.

Narayanan, V. G. 2000. Cambridge Hospital Community Health Network-The primary care unit. HBS no. 9-100-054. Boston: Harvard Business School Publishing.
Nordling, C. W., and S. K. Wheeler. 1992. Building a marketsegment accounting model to improve profits. Cornell Hotel and Restaurant Administration Quarterly 33 (3): 29-36.

O'Neill, J. W., and A. S. Mattila. 2006. Strategic hotel development and positioning: The effects of revenue drivers on profitability. Cornell Hotel and Restaurant Administration Quarterly 47 (2): 146-54.

Parsa, H. G., J. T. Self, D. Njite, and T. King. 2005. Why restaurants fail. Cornell Hotel and Restaurant Administration Quarterly 46 (3): 304-22.

Pavesic, D. V. 1983. The myth of labor-cost percentages. Cornell Hotel and Restaurant Administration Quarterly 24 (3): 27-30.

Quain, W. J. 1992. Analyzing sales-mix profitability. Cornell Hotel and Restaurant Administration Quarterly 33 (2): 56-62.

Redlin, M. H., and L. M. Goland. 1984. Submetering of hotel utilities. Cornell Hotel and Restaurant Administration Quarterly 24 (3): 45-50.

Reynolds, D. 1999. Inventory-turnover analysis: Its importance for on-site food service. Cornell Hotel and Restaurant Administration Quarterly 40 (2): 54-58.

Schmidgall, R. S., J. W. Damitio, and A. J. Singh. 1997. What is a capital expenditure? Cornell Hotel and Restaurant Administration Quarterly 38 (4): 28-33.

Schmidgall, R. S., and A. L. DeFranco. 1998. Budgeting and forecasting: Current practice in the lodging industry. Cornell Hotel and Restaurant Administration Quarterly 39 (6): 45-51.

Schmidgall, R. S., A. N. Geller, and C. L. Ilvento. 1993. Financial analysis using the statement of cash flows. Cornell Hotel and Restaurant Administration Quarterly 34 (1): 46-53.

Staw, B. M. 1976. Knee-deep in the big muddy: A study of escalating commitment to a chosen course of action. Organizational Behavior and Human Performance 16:27-44.

Tracey, J. B., and T. R. Hinkin. 2008. Contextual factors and cost profiles associated with employee turnover. Cornell Hospitality Quarterly 49 (1): 12-27.

Upneja, A., and R. Schmidgall. 2001. Equipment leasing in the U.S. lodging industry: What, why, and how much. Cornell Hotel and Restaurant Administration Quarterly 42 (2): 56-61.

\section{Bios}

James W. Hesford, Ph.D., is an assistant professor of accounting at the Cornell University School of Hotel Administration (jh383@ cornell.edu). Gordon Potter, Ph.D., C.P.A., is an associate professor of accounting (gsp6@cornell.edu). 